\title{
Immunoreactive leptin and leptin mRNA expression are increased in rat hypo- but not hyperthyroidism
}

\author{
U Leonhardt ${ }^{1}$, E Gerdes, U Ritzel ${ }^{1}$, G Schäfer, W Becker ${ }^{2}$ and \\ G Ramadori ${ }^{1}$ \\ ${ }^{1}$ Department of Medicine, Division of Gastroenterology and Endocrinology, University of Göttingen, Göttingen, Germany \\ ${ }^{2}$ Department of Nuclear Medicine, University of Göttingen, Göttingen, Germany \\ (Requests for offprints should be addressed to U Leonhardt, Department of Medicine, Division of Gastroenterology and Endocrinology, \\ Robert-Koch-Straße 40, D-37075 Göttingen, Germany)
}

\begin{abstract}
In this study, plasma leptin concentrations were measured in rats artificially rendered hyper- or hypothyroid by administration of thyroxine or TRH, by administration of methimazole, or by thyroidectomy. Compared with those in untreated controls, leptin immunoreactivity was not affected in the hyperthyroid state, but was significantly increased in hypothyroid animals. Methimazole administration for longer time periods caused a stepwise increase in plasma leptin immunoreactivity. Greatest leptin concentrations were seen after 28 days of methimazole. Seven days after withdrawal of the methimazole, leptin concentrations no longer differed from those observed in control
\end{abstract}

animals. In hypothyroid animals, expression of leptin mRNA was increased in both retroperitoneal and epididymal adipose tissue, whereas no difference was seen for subcutaneous or mesenteric fat. Incubation of rat leptin with plasma of eu- or hypothyroid rats and subsequent HPLC analysis of leptin plasma peaks gave no indication of an altered hormone stability. We conclude that, in hypothyroid rats, leptin concentrations may be increased as a result of stimulated leptin synthesis in retroperitoneal and epididymal adipose tissue.

Journal of Endocrinology (1999) 163, 115-121

\section{Introduction}

Alterations in the hormonal state of the thyroid gland are frequently associated with changes in body weight. In hypothyroidism, body mass index is often increased, whereas in hyperthyroidism there is a tendency to weight loss (Ingbar 1985, Romiti et al. 1998, Wesche et al. 1998). A correlation has been established between circulating concentrations of thyroid hormones and energy expenditure (Macari et al. 1986, Iossa et al. 1996). Energy homeostasis, body weight, and food uptake are also regulated by leptin, the protein product of the $o b$ gene (Zhang et al. 1994, Rohner-Jeanrenaud \& Jeanrenaud 1996, Roth et al. 1998). Thus it is conceivable that leptin might have a role in different states of thyroidal disease. Accordingly, a possible relationship has been the subject of several studies, but no uniform picture has yet emerged from the results. Whereas Valcavi et al. (1997) found significantly reduced serum leptin concentrations before and during replacement therapy in patients with hypothyroidism caused by autoimmune disease, others did not see alterations in serum leptin in different hypothyroid states (Sreenan et al. 1997, Ozata et al. 1998). However, we recently reported increased leptin concentrations in patients with primary hypothyroidism or thyroid carcinoma compared with euthyroid controls (Leonhardt et al. 1998). In the present study, experimental models of artificially induced thyroidal dysfunction were used to investigate plasma leptin concentrations and leptin mRNA expression in hypo- and hyperthyroidism.

\section{Materials and Methods}

\section{Animals}

Male Wistar rats (200-220 g) were maintained in conditions of constant temperature $\left(21^{\circ} \mathrm{C}\right)$ and humidity with a $12 \mathrm{~h}$ light:12 h darkness cycle. Animals were kept singly in cages, on grids to prevent coprophagia. Body weight was monitored daily. All animals were allowed to drink water ad libitum. Each rat received $20 \mathrm{~g}$ rat chow per day. The experimental procedure was approved by the local committee for animal protection.

\section{Endocrinological manipulations}

For manipulations of thyroid status, 50 rats were divided into five groups. Two groups were made artificially thyrotoxic by being given $10 \mu \mathrm{g}$ thyroxine $\left(\mathrm{T}_{4}\right)$ (group 1 ) 
or $40 \mathrm{mg}$ thyrotropin-releasing hormone (TRH) (group 2) daily with their food, a control group were fed $20 \mathrm{~g}$ rat chow per day (group 3), one group were made chemically hypothyroid by being given $10 \mathrm{mg}$ methimazole daily with their food (group 4), and one group were thyroidectomized animals, purchased postoperatively (group 5). Chemically treated and control animals were killed after 14 days of feeding. Thyroidectomized animals did not receive supplements for their hormone deficiency and were killed 14 days after thyroidectomy.

In a further set of experiments, time dependency of the effect seen with methimazole treatment was studied by measuring plasma leptin concentrations in rats killed after $0,3,6,9,14$, and 28 days of drug feeding and 7 days after drug withdrawal (10 animals each).

\section{Quantification of hormones}

Thyroid hormones and thyroid-stimulating hormone (TSH) were measured in plasma samples collected as described below. Tri-iodothyronine $\left(\mathrm{T}_{3}\right)$ and free plasma $\mathrm{T}_{4}$ (fT4) were quantified by competitive immunoassays (Ciba Corning Diagnostics, Fernwald, Germany) and TSH by a two-sided chemiluminometric (sandwich) immunoassay (Ciba Corning Diagnostics).

\section{Leptin RIA}

For determination of plasma immunoreactive leptin, after a 6-h fasting period, heparinized blood samples were drawn from animals via a catheter in the carotid artery. Samples were centrifuged immediately for $15 \mathrm{~min}$ at $4{ }^{\circ} \mathrm{C}$ and plasma was aliquoted and stored at $-70{ }^{\circ} \mathrm{C}$ until required for assay. We quantified plasma leptin concentrations using a commercial RIA kit (Linco Research Inc., St Charles, MO, USA). Duplicate leptin determinations were made from each sample, and all plasma and gel chromatography samples were run in the same assay. The assay was set up in $100 \mu \mathrm{l} 0.05 \mathrm{M}$ phosphate EDTA buffer with addition of $1 \%$ RIA-grade bovine serum albumin, and a $100 \mu \mathrm{l}$ sample volume was added. Samples were incubated overnight at room temperature, with $100 \mu \mathrm{l}$ rat leptin antibody in all tubes except those for non-specific binding. After addition of $100 \mu{ }^{125}$ I-labelled rat leptin, incubation was continued overnight. The next day, $1 \mathrm{ml}$ precipitating agent was added, followed by an incubation period of $20 \mathrm{~min}$ at $4{ }^{\circ} \mathrm{C}$. The leptin-antibody complex was separated by centrifugation for $20 \mathrm{~min}$ at $2500 \boldsymbol{g}$ at $4{ }^{\circ} \mathrm{C}$, and radioactivity in the pellet was counted. For crossreactivity studies, $\mathrm{T}_{3}, \mathrm{fT}_{4}$, and $\mathrm{TSH}$ were assayed in concentrations of $1,5,10,50$ and $100 \mathrm{nmol} /$ tube.

\section{Gel chromatography}

Gel chromatography of pooled plasma samples was performed to confirm the specificity of the rat antibody. A

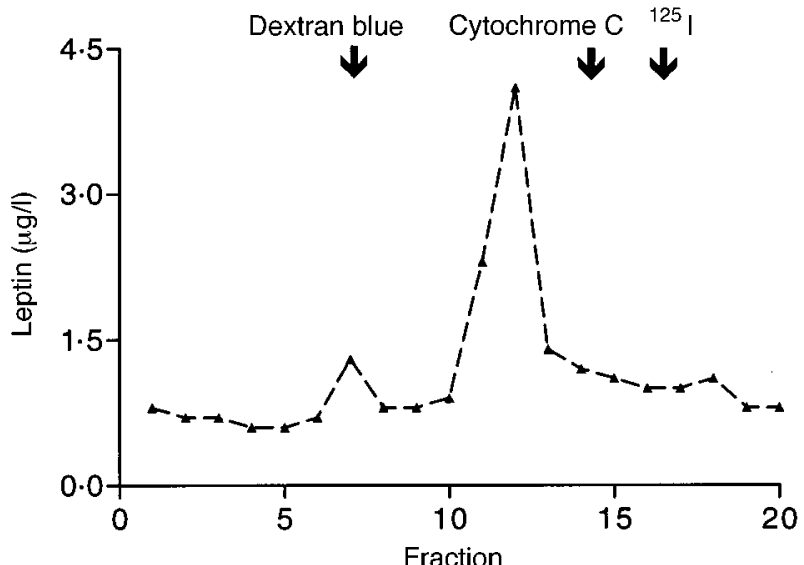

Figure 1 Gel chromatography (G75 Sephadex) of a plasma sample. The major peak (87\%) of leptin plasma radioactivity eluted at the position of rat leptin.

Sephadex G-75 column (length $26.5 \mathrm{~cm}$, diameter $3.5 \mathrm{~cm}$ ) was used with Dextran blue, cytochrome C, and iodine-125 as markers for molecular size in collected fractions. Mean recovery expressed as percentage of the amount of peptide found in assayed fractions related to the amount of peptide loaded onto the column was $61 \%(n=6$, range $53-78 \%)$. The major peak of leptin plasma radioactivity $(87 \%)$ eluted at the position of rat leptin and $11 \%$ at $2000 \mathrm{kDa}$, most probably representing leptin bound to larger plasma proteins (Fig. 1).

\section{High performance liquid chromatography}

Plasma samples $(100 \mu \mathrm{l})$ from hypo- and euthyroid rats were incubated for $0,15,30$, and $60 \mathrm{~min}$ with $20 \mu \mathrm{g}$ rat leptin at room temperature. The incubation was terminated by addition of $20 \mu \mathrm{l}$ aqueous $10 \%$ trifluoroacetic acid (TFA). The samples were applied to $\mathrm{C}_{18}$ reverse-phase (RP) cartridges (size $3 \mathrm{ml} / 100 \mathrm{mg}$; Bond Elut; Varian, Harbor City, CA, USA), washed with $2 \mathrm{ml}$ aqueous $0 \cdot 1 \%$ TFA, and eluted with $0.5 \mathrm{ml} 60 \%$ acetonitrile in aqueous $0 \cdot 1 \%$ TFA. After lyophilization and dissolution of the samples in $100 \mu \mathrm{l}$ solvent A ( $0 \cdot 1 \%$ TFA in water), analytical RP-HPLC was performed on a Nucleosil $\mathrm{C}_{18}$ silica gel column (30 nm pore size, $7 \mu \mathrm{m}$ particle size; MachereyNagel, Düren, Germany) with solvents A and B (70\% acetonitrile in $0.1 \%$ TFA in water) at a flow rate of $1.5 \mathrm{ml} / \mathrm{min}$. The peptides were eluted with a linear gradient of solvent B from 30 to $70 \%$ over 40 min using chromatography pumps (Waters, Eschborn, Germany) equipped with an automated gradient controller (Waters). Elution of the peptides was monitored by measuring u.v. absorption at $220 \mathrm{~nm}$ (LKB 2151 variable wavelength monitor; Pharmacia, Freiburg, Germany).

\section{RNA isolation}

Adipose tissue from epididymal, mesenteric, subcutaneous and retroperitoneal fat pads were collected from 
Table 1 Serum concentrations of $\mathrm{TSH}_{1} \mathrm{~T}_{3}$ and $\mathrm{fT}_{4}$ in eu-, hypo- or hyperthyroid rats. Details of endocrinological manipulations are given in the Materials and Methods section. Values are means \pm S.E.M.

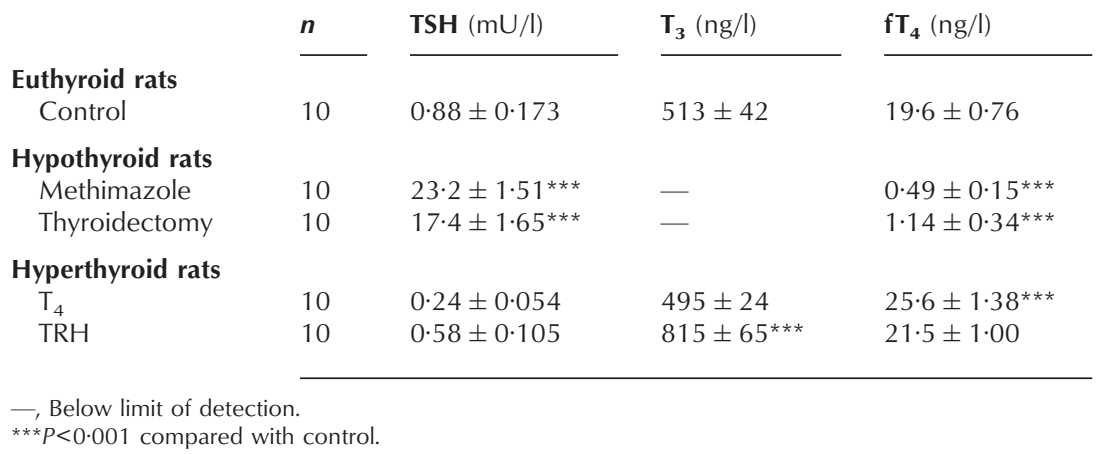

methimazole-treated, thyroidectomized, and control animals, immediately snap-frozen in liquid nitrogen and stored at $-70{ }^{\circ} \mathrm{C}$. For RNA extraction, frozen specimens were ground finely at $-70{ }^{\circ} \mathrm{C}$ and lysed in $3 \mathrm{ml} 4 \mathrm{M}$ guanidine thiocyanate. Total RNA was isolated by caesium chloride gradient centrifugation of the $3 \mathrm{ml}$ guanidine samples layered on $2 \mathrm{ml}$ of a caesium chloride solution $(5 \cdot 7 \mathrm{M})$. Centrifugation at 35000 r.p.m. (Centrikon t 2070 , Neufahrn, Germany) for $18 \mathrm{~h}$ at $20^{\circ} \mathrm{C}$ resulted in a pellet, which was washed twice with $70 \%$ ethanol and resuspended in RNAse-free distilled water. Thereafter, RNA was precipitated with $20 \mu \mathrm{l} 2 \mathrm{M}$ sodium acetate and $400 \mu$ ethanol (100\%) overnight at $-20{ }^{\circ} \mathrm{C}$. In the following step, RNA was separated by centrifugation at 22000 r.p.m. for $15 \mathrm{~min}$ at $4{ }^{\circ} \mathrm{C}$ and dissolved in $50 \mu \mathrm{l}$ distilled water. Messenger RNA concentration was quantified by photodensitometry at 260/280 $\mathrm{nm}$.

\section{Northern blot analysis}

Total RNA (10 $\mu \mathrm{g}$ per lane) was fractionated on an ethidium bromide-stained 1\% agarose gel, which was blotted overnight onto a charged nylon membrane (Hybond-N+, Amersham, Braunschweig, Germany), by capillary blotting with $20 \times$ SSC blotting buffer $(3 \mathrm{M}$ sodium chloride, $0 \cdot 3 \mathrm{M}$ sodium citrate). Membranes were pre-hybridized for $1 \mathrm{~h}$ at $68^{\circ} \mathrm{C}$ (Quick-hybridisationsolution, Stratagene, Heidelberg, Germany) and hybridized for $2 \mathrm{~h}$ at $68^{\circ} \mathrm{C}$ with labelled cDNA probes $(50 \mathrm{ng}$ ). The cDNAs were labelled with phosphorus-32 using Pharmacia-Quick-Prime Kit (Pharmacia, Vienna, Austria). After hybridization, membranes were washed twice with $100 \mathrm{ml} 2 \times \mathrm{SSC}+0 \cdot 1 \% \mathrm{SDS}$ for $30 \mathrm{~min}$ at room temperature and once for $2 \mathrm{~min}$ at $56^{\circ} \mathrm{C}$. Membranes were exposed to radiographic film (Kodak Scientific Imaging Film; X-OMAT AR) at $-70{ }^{\circ} \mathrm{C}$ for 3 days. Autoradiographs were quantified by densitometry using Scion Image (Molecular Dynamics, Krefeld, Germany). As membranes were sequentially hybridized with two different cDNA probes, the ${ }^{32} \mathrm{P}$-labelled cDNA was removed after autoradiography by two washing steps with boiling $0 \cdot 1 \% \mathrm{SSC} / 0 \cdot 1 \% \mathrm{SDS}$.

The probes were the cDNA of rat leptin RNA, a 33-mer antisense oligonucleotide with the sequence $5^{\prime}$ GGT CTG AGG CAG GGA GCA GCT CTT GGA GAA GGC-3', synthesized by MWG Biotech (Ebersberg, Germany) and a 27-mer oligonucleotide with the sequence $5^{\prime}$-AAC GAT CAG AGT AGT TGG TAT TTC ACC-3' (MWG Biotech) targeted to $28 \mathrm{~S}$ ribosomal RNA. The intensities of bands of $28 \mathrm{~S}$ ribosomal RNA were compared with those of leptin RNA on the same blot, and used as a reference for quantification of leptin mRNA expression.

\section{Statistical analysis}

Data are shown as mean values \pm S.E.M. (standard error of the mean). Statistical analysis was performed using Prism Program (GraphPad Software, Version 2·0, San Diego, CA, USA). Data were compared by one-way ANOVA using the Bonferroni test for selected pairs of columns for post hoc analysis. Differences were considered significant at $P<0 \cdot 05$.

\section{Results}

Body weights and plasma leptin immunoreactivity

Quantification of thyroid hormones confirmed hypothyroidism after thyroidectomy and methimazole treatment, and hyperthyroidism induced by thyroxine or TRH (Table 1). At the end of the treatment period, mean body weights of $243 \pm 2 \cdot 5,263 \pm 7 \cdot 6,251 \pm 2 \cdot 0,247 \pm 3 \cdot 8$, and $256 \pm 7 \cdot 3 \mathrm{~g}$ were measured for animals of groups 1 (hyperthyroid), 2 (hyperthyroid), 3 (control), 4 (hypothyroid), and 5 (hypothyroid) respectively. Values of treatment groups did not differ significantly from those seen in euthyroid controls. 


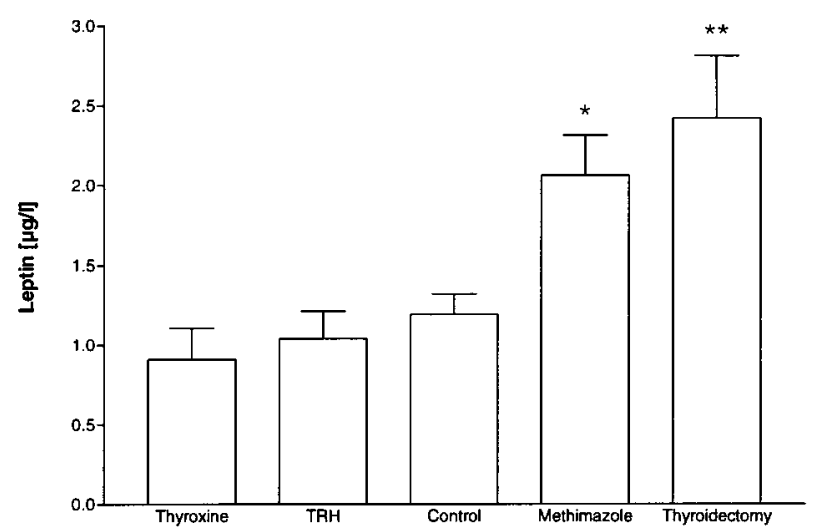

Figure 2 Plasma leptin concentrations in rats in response to thyroid state $(n=10$ each group). Values are means \pm S.E.M. ${ }^{*} P<0 \cdot 05,{ }^{*} P<0 \cdot 01$ compared with control.

Leptin immunoreactivity in both thyroxine- and TRH-treated rats was unchanged compared with controls (thyroxine, 0.91 $\pm 0.20 \mu \mathrm{g} / \mathrm{l}$; TRH, $1 \cdot 04 \pm 0 \cdot 17 \mu \mathrm{g}$ / 1 ; controls, $1 \cdot 19 \pm 0.25 \mu \mathrm{g} / 1 ; n=10$ in each group). Hypothyroidism induced by methimazole or thyroidectomy resulted in significantly increased leptin concentrations $(2 \cdot 06 \pm 0.25 \mu \mathrm{g} / 1$ and $2.42 \pm 0.39 \mu \mathrm{g} / 1$ compared with $1 \cdot 19 \pm 0.25 \mu \mathrm{g} / 1$ in controls; $P<0 \cdot 05$ and $P<0 \cdot 01$ respectively), but the difference in leptin concentrations between the two models of hypothyroidism was not significant (Fig. 2). Qualitatively, the same findings emerged when leptin concentrations were corrected for body weight. In thyroxine- and TRH-treated rats, leptin values of $0.38 \pm 0.08$ and $0.40 \pm 0.07 \mu \mathrm{g} / 1$ per $100 \mathrm{~g}$ were found, compared with $0.48 \pm 0.05 \mu \mathrm{g} / 1$ per $100 \mathrm{~g}$ in controls. Corresponding values for methimazole treatment and thyroidectomy groups were $0.83 \pm 0.10$ and $0 \cdot 92 \pm \mu \mathrm{g} / 1$ per $100 \mathrm{~g}(P<0 \cdot 05$ and $P<0 \cdot 01$, respectively, compared with control).

\section{Time-dependent effect of methimazole}

Administration of methimazole for 3 and 6 days significantly reduced $T_{3}$ and $f T_{4}$, increased TSH, but did not affect leptin concentrations $(0.87 \pm 0.13 \mu \mathrm{g} / 1$ and $1 \cdot 08 \pm 0 \cdot 17 \mu \mathrm{g} / 1$ respectively; Fig. 3). After 9 days of methimazole treatment, an increase in leptin concentration became apparent $(1.93 \pm 0.31 \mu \mathrm{g} / \mathrm{l})$; it reached statistical significance after $14(2 \cdot 06 \pm 0.25 \mu \mathrm{g} / 1, P<0 \cdot 05)$ and 28 days $(2 \cdot 31 \pm 0 \cdot 35 \mu \mathrm{g} / 1, P<0 \cdot 01$; all comparisons are with the control value of $1 \cdot 19 \pm 0 \cdot 25 \mu \mathrm{g} / \mathrm{l} ; n=10 \mathrm{each}$ ) (Fig. 3). Seven days after withdrawal of methimazole, plasma concentrations of leptin and those of thyroid hormones had returned to control values (Fig. 3).

\section{Incubation of leptin with plasma of eu- and hypothyroid rats}

Analysis of HPLC elution curves showed an immediate recovery of $87 \%$, decreasing to $57 \%$ after incubation for
$2 \mathrm{~h}$. The area under the curve of leptin peaks did not indicate a difference at any time point when incubation experiments with plasma of hypothyroid rats were compared with those of euthyroid controls.

\section{Northern blot analysis}

In hypothyroid animals, northern blot analysis consistently revealed enhanced expression of leptin mRNA both in retroperitoneal and epididymal adipose tissue, but not in subcutaneous or mesenteric fat, when compared with controls. Increases were 1.14- and 1.43-fold with thyroidectomy and 1.33- and 1.37-fold with methimazole treatment for the retroperitoneal and epididymal adipose tissue respectively (given as intensities of bands of leptin RNA relative to those of $28 \mathrm{~S}$ ribosomal RNA and being means from three independent experiments). A representative autoradiograph is shown in Fig. 4.

\section{Discussion}

The results of this study show that plasma leptin concentrations, and expression of leptin mRNA in adipose tissues of distinct origin, are increased in male Wistar rats rendered hypothyroid by either drug treatment or thyroidectomy.

Plasma leptin concentrations are known to increase with the percentage of body fat and, to a lesser extent, with body mass index. As body weights of hypo- or hyperthyroid rats did not differ from those of their euthyroid counterparts, it is unlikely that changes in leptin concentrations merely reflect altered weight secondary to thyroid disease. However, we did not analyse the body composition of the animals, therefore we cannot exclude the possibility that group differences in the proportions of fat mass to lean body mass may have contributed to the findings.

Modification of leptin degradation in rat plasma by hypothyroidism probably does not explain the changes observed, because, in both hypothyroid models, plasma metabolism of the peptide remained unaffected compared with that in controls. Enhancement of leptin concentrations in hypothyroid animals was also not attributable to crossreactivity, as the antibody used for RIA did not bind thyroid hormones or TSH. Gel chromatographic runs of plasma samples indicated that the antibody detected the complete and intact $o b$ gene protein. Moreover, the onset of hypothyroidism preceded leptin enhancement, and normalization occurred after withdrawal of thyrostatic medication. Likewise, the increased leptin concentrations in hypothyroidism were probably not a direct effect of methimazole treatment, as leptin was increased both in drug-induced hypothyroidism and after thyroidectomy.

Our data indicate that hypothyroidism directly affects plasma leptin concentrations by modifying leptin mRNA 

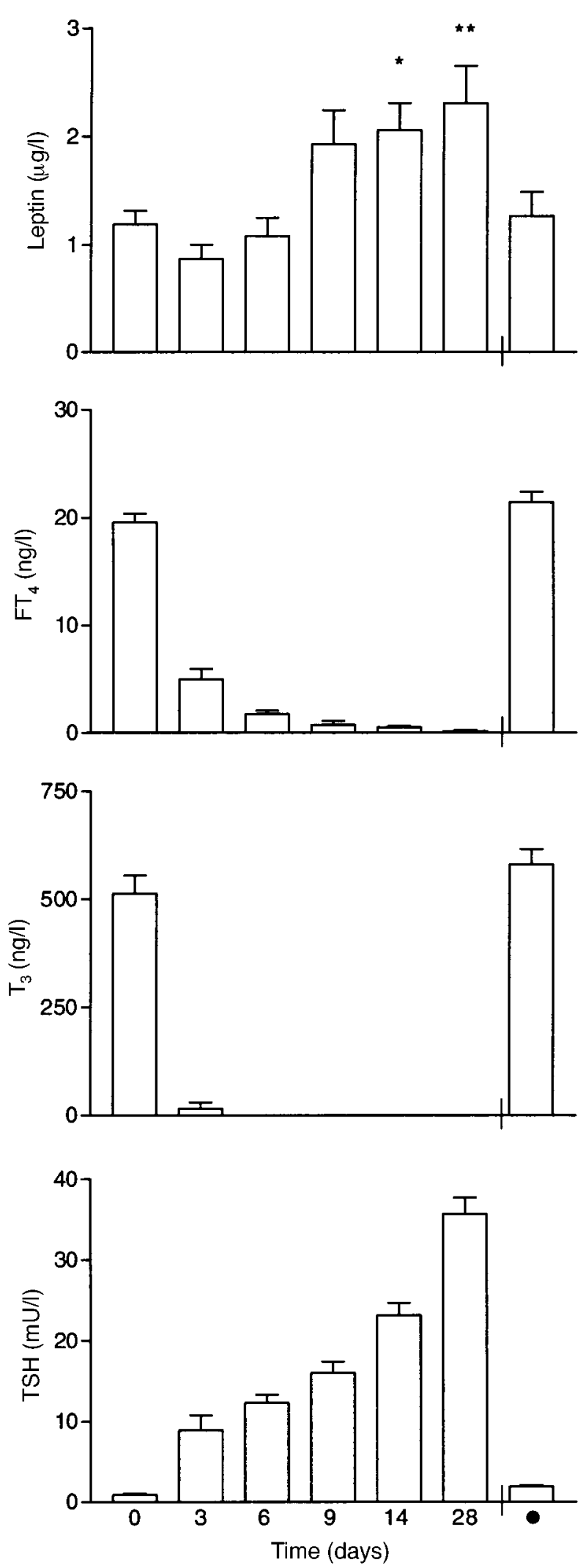

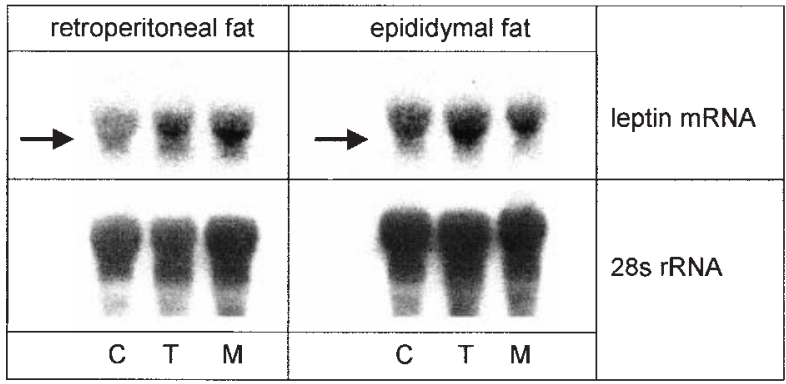

Figure 4 Autoradiograph of leptin mRNA (arrow) in rat retroperitoneal or epididymal adipose tissue. C, controls; $\mathrm{T}$, thyroidectomized; $M$, methimazole-treated (14 days). Upper panel: hybridization with a leptin-specific probe. Lower panel: $28 \mathrm{~S}$ ribosomal RNA.

expression in retroperitoneal and epididymal adipose tissue. This is in agreement with results reported by Fain et al. (1997) who measured an approximately 1.6-fold expression of leptin mRNA in epididymal fat pads of hypothyroid rats, compared with euthyroid controls. This increase in leptin mRNA concentrations was reversed within $8 \mathrm{~h}$ after $\mathrm{T}_{3}$ administration, followed by an approximately $50 \%$ reduction in serum leptin concentrations at $24 \mathrm{~h}$ after hormone injection.

Because hypothyroid patients usually exhibit modestly increased body weight and decreased appetite, our results might indicate that the overall alterations in food intake and energy expenditure present in hypothyroidism are not mediated primarily by leptin. This is in agreement with the recent hypothesis that leptin, although initially identified as a satiety hormone, functions to prevent starvation and maintain reproductive capacity (Coleman \& Herrmann 1999). It has not been proven that serum leptin affects energy intake or satiety in humans: numerous studies have shown that, in obese people, high leptin concentrations are associated with excess, rather that diminished, food intake. Postprandial leptin concentrations do not correlate with immediate subjective feelings of hunger, and are not significantly different between two meals that induce different effects on appetite (Joannic et al. 1998).

Escobar-Morreale et al. (1997) reported a decrease in serum leptin in hypothyroid female rats that were given substitute thyroid hormones to produce a euthyroid state. In contrast to our study design, their experimental setting led to marked differences in body weight, and higher leptin concentrations, compared with controls, were seen

Figure 3 Effect of administration of methimazole for different periods in 10 rats. $\bullet$, Leptin concentrations 7 days after withdrawal of methimazole. Values are means \pm S.E.M. ${ }^{*} P<0 \cdot 05$, ${ }^{*} P<0.01$ compared with day 0 . On days $3-28$, concentrations of $\mathrm{fT}_{4}, \mathrm{~T}_{3}$, and TSH differed significantly $(P<0 \cdot 001)$ from those on day 0 . 
in hypothyroidism after correction for body weight only. No further decreases were achieved, however, by excess substitution to levels representing hyperthyroid states, which is in accordance with the finding of unaltered plasma leptin concentrations in our models of hyperthyroidism, compared with euthyroid animals. Likewise, administration of thyroid hormones to healthy human volunteers did not change circulating leptin, although cardiovascular and metabolic effects were present (Mantzoros et al. 1997), and plasma leptin remained unaltered in mildly to moderately hyperthyroid patients (Corbetta et al. 1997, Valcavi et al. 1997).

A similar pattern as seen in the present study of the leptin response to changes in the thyroid status was described previously in human disease, with circulating leptin being increased in hypothyroidism, but not in hyperthyroidism (Leonhardt et al. 1998, Pinkney et al. 1998). However, conflicting data exist on the significance of the thyroid state for serum leptin concentrations (Corbetta et al. 1997, Sreenan et al. 1997, Valcavi et al. 1997, Yoshida et al. 1998, Ozata et al. 1998). As human leptin concentrations have been reported to show both circadian changes (Sinha et al. 1996) and a high degree of pulsatility (Licinio et al. 1997), sampling conditions might be relevant for leptin quantification, in addition to the severity and duration of thyroid dysfunction.

As regards the time dependence of the effects of methimazole, drug-induced suppression of thyroid hormone synthesis was already effective on day 3 , although $\mathrm{fT}_{4}$ concentrations still amounted to $25 \%$ of the control value at this time, and were $9 \%$ of control on day 6 . At $\mathrm{fT}_{4}$ values less than $4 \%$ of control (day 9), an effect on plasma leptin concentrations became apparent. It might be assumed that marginal concentrations of circulating thyroid hormone are sufficient to maintain leptin concentrations within a certain range. Results presented by Escobar-Morreale et al. (1997), which showed fairly constant leptin concentrations over a broad range of rat plasma $T_{3}$ or $T_{4}$ concentrations, lend support to this assumption. Thyroid hormones not only may influence the leptin system in rather low concentrations, but also rather rapidly. Fain et al. (1997) observed a 40\% reduction in leptin mRNA expression in rat epididymal adipose tissues as soon as $8 \mathrm{~h}$ after injection of $\mathrm{T}_{3}$ to hypothyroid rats. Moreover, $\mathrm{T}_{3}$, given to such animals $8 \mathrm{~h}$ before death, inhibited leptin release by adipocytes in vitro (Fain \& Bahouth 1998).

The site specificity of leptin mRNA modulation by thyroid hormones found in the present study has, to our knowledge, not been reported before. Differential modification of ob gene mRNA expression has, however, been described in rat white adipose tissues from different sites after ovariectomy (Shimizu et al. 1997) or with lesions of the ventromedial hypothalamus (Satoh et al. 1997).

In summary, we conclude from our results that hypothyroidism in rats increases plasma leptin concen- trations by increased leptin synthesis in retroperitoneal and epididymal adipose tissue.

\section{References}

Colemann RA \& Herrmann TS 1999 Nutritional regulation of leptin in humans. Diabetologia 42 639-646.

Corbetta S, Englaro P, Giambona S, Persani L, Blum WF \& Beck-Peccoz P 1997 Lack of effects of circulating thyroid hormone levels on serum leptin concentrations. European Journal of Endocrinology 137 659-663.

Escobar-Morreale HF, Escobar del Rey F \& Morreale de Escobar G 1997 Thyroid hormones influence serum leptin concentrations in the rat. Endocrinology 138 4485-4488.

Fain JN \& Bahouth SW 1998 Effect of tri-iodothyronine on leptin release and leptin mRNA accumulation in rat adipose tissue. Biochemical Journal 332 361-366.

Fain JN, Coronel EC, Beauchamp MJ \& Bahouth SW 1997 Expression of leptin and $\beta_{3}$-adrenergic receptors in rat adipose tissue in altered thyroid states. Biochemical Journal 322 145-150.

Ingbar SH 1985 The thyroid gland. In Textbook of Endocinology, pp 957-1170. Eds JD Wilson \& DW Foster. Philadelphia: Saunders.

Iossa S, Lionetti L, Mollica MP, Barletta A \& Liverini G 1996. Thermic effect of food in hypothyroid rats. Journal of Endocrinology 148 167-174.

Joannic JL, Oppert JM, Lahlou N, Basdevant A, Auboiron S, Raison J, Bornet F \& Guy-Grand B 1998 Plasma leptin and hunger ratings in healthy humans. Appetite 30 129-138.

Leonhardt U, Ritzel U, Schäfer G, Becker W \& Ramadori G 1998 Serum leptin levels in hypo- and hyperthyroidism. Journal of Endocrinology 157 75-79.

Licinio J, Mantzoros C, Negrao AB, Cizza G, Wong ML, Bongiorno PB, Chrousos GP, Karp B, Allen C, Flier JS \& Gold PW 1997 Human leptin levels are pulsatile and inversely related to pituitaryadrenal function. Nature Medicine 3 575-579.

Macari M, Zuim SMF, Secato ER \& Guerero JR 1986 Effects of ambient temperature and thyroid hormones on food intake in pigs. Physiology and Behaviour 36 1035-1039.

Mantzoros CS, Rosen HN, Greenspan SL, Flier JS \& Moses AC 1997 Short-term hyperthyroidism has no effect on leptin levels in man. Journal of Clinical Endocrinology and Metabolism 82 497-499.

Ozata M, Ozisik G, Bingol N, Corakci A \& Gundogan MA 1998 The effect of thyroid status on plasma leptin levels in women. Journal of Endocrinological Investigation 21 337-341.

Pinkney JH, Goodrick SJ, Katz J, Johnson AB, Lightman SL, Coppack SW \& Mohamed-Ali V 1998 Leptin and the pituitary-thyroid axis: a comparative study in lean, obese, hypothyroid and hyperthyroid subjects. Clinical Endocrinology 49 583-588.

Rohner-Jeanrenaud F \& Jeanrenaud B 1996 Obesity, leptin, and the brain. New England Journal of Medicine 334 324-325.

Romiti A, Buzzetti R, Salandri A, Festuccia F, Giovannini CA, Santella S, Montesani C \& Giovannini C 1998 Thyroid tumors in obesity. Minerva Endocrinologica 23 27-29.

Roth C, Wilken B, Hanefeld F, Schröter W \& Leonhardt U 1998 Hyperphagia in children with craniopharyngioma is associated with hyperleptinaemia and a failure in the downregulation of appetite. European Journal of Endocriology 138 89-91.

Satoh N, Ogawa Y, Katsuura G, Tsuji T, Masuzaki H, Hiraoka J, Okazaki T, Tamaki M, Hayase M, Yoshimasa Y, Nishi S, Hosoda K \& Nakao K 1997 Pathophysiological significance of the obese gene product, leptin, in ventromedial hypothalamus (VMH)lesioned rats: evidence for loss of its satiety effect in VMH-lesioned rats. Endocrinology 138 947-954. 
Shimizu H, Shimomura Y, Nakanishi Y, Futawatari T, Ohtani K, Sato N \& Mori M 1997 Estrogen increases in vivo leptin production in rats and human subjects. Journal of Endocrinology 154 285-292.

Sinha MK, Ohannesian JP, Heiman ML, Kriauciunas A, Stephens TW, Magosin S, Marco C \& Caro JF 1996 Nocturnal rise of leptin in lean, obese, and non-insulin-dependent diabetes mellitus subjects. Journal of Clinical Investigation 97 1344-1347.

Sreenan S, Caro JF \& Refetoff S 1997 Thyroid dysfunction is not associated with alterations in serum leptin levels. Thyroid 7 407-409.

Valcavi R, Zini M, Peino R, Casanueva FF \& Dieguez C 1997 Influence of thyroid status on serum immunoreactive leptin levels. Journal of Clinical Endocrinology and Metabolism 82 1632-1634.
Wesche MF, Wiersinga WM \& Smits NJ 1998 Lean body mass as a determinant of thyroid size. Clinical Endocrinology 48 701-706.

Yoshida T, Momotani N, Hayashi M, Ito K \& Saruta T 1998 Serum leptin concentrations in patients with thyroid disorders. Clinical Endocrinology 48 299-302.

Zhang Y, Proenca R, Maffei M, Barone M, Leopold L \& Friedman JM 1994 Positional cloning of the mouse obese gene and its human homologue. Nature 372 425-432.

Received 4 March 1999

Accepted 11 June 1999 